\title{
SZENT HILARION ÉS A KOCSIVERSENY
}

\author{
NÉMETH GYÖRGY ${ }^{1}$
}

\begin{abstract}
The conversion from Paganism to Christianity was a slow process. Pagan magic was palpable reality for Christians, and they indeed took the field against it, as it is confirmed by the biography of Saint Hilarion. Hilarion (291-371) was a hermit and the founder of Palestinian monasticism. His biography was written by St. Hieronymus around 390 in Betlehem. Hilarion exorcised demons and healed the sick.
\end{abstract}

A pogány mágia a korai keresztények számára is kétségbevonhatatlan valóság volt, és olykor fel is vették ellene a harcot, amint ezt Szent Hilarion életrajzában olvashatjuk. Hilarion (291-371) remete volt, és a palaestinai monaszticizmus alapítója. Életrajzát Szent Jeromos írta meg 390 körül Betlehemben. ${ }^{2}$ A 47 fejezetből álló életrajzból megtudhatjuk, hogy a kivételesen hosszú életű Hilarion kérésre démonokat űzött el és betegeket gyógyított. Egy alkalommal egy gazai kocsihajtó életét kellett megmentenie. A kocsihajtók ellen irányuló varázslatok igen gyakoriak voltak, mivel a kocsiversenyekre nagy összegben lehetett fogadni, így nem csoda, hogy a nyereményt minden eszközzel, akár az ellenfél megátkozásával is megpróbálták bebiztosítani. Ilyen átok érhette a gazai kocsihajtót is.

„16. Auriga quoque Gazensis in curru percussus a daemone, totus obriguit; ita ut nec manum agitare, nec cervicem posset [al. possit] reflectere. Delatus ergo in lecto, cum solam linguam moveret ad preces, audit non prius posse sanari, quam crederet in Iesum, et se sponderet arti pristinae renuntiaturum. Credidit, spopondit, sanatus est: magisque de animae, quam de corporis salute exsultavit.”

\footnotetext{
${ }^{1}$ ELTE BTK Ókortörténeti Tanszék, ORCID oooo-ooo1-8708-8102.

${ }^{2}$ Lásd Weingarten.
} 
„Egy kocsihajtóra, aki szintén gazai volt, démon sújtott le, amitől teljesen megbénult, még a kezét sem tudta megmozdítani, nyakát sem tudta hajlítani. Hordágyra tették, de ő csak nyelve mozgatásával tudta kifejezni kérését. Azt a választ kapta, hogy csak azután gyógyulhat meg, ha hinni fog Jézusban, és ígéretet tesz, hogy felhagy korábbi foglalkozásával. Hitt, ígéretet tett és meggyógyult. Jobban örvendett lelke, mint teste gyógyulásának.”3

Még érdekesebb az az eset, amikor a szent képességeit egy pogány mágus mesterkedése ellen kellett felhasználni. A történet bizonyítja, hogy a pogányok és a keresztények egyaránt hittek a mágusok erejében, és a varázslatok elhárításában akár még egy szent is részt vehetett.

„20. Sed et Italicus eiusdem oppidi municeps Christianus, adversus Gazensem Duumvirum, Marnae idolo deditum, Circenses equos [al. circi equos curules] nutriebat. Hoc siquidem in Romanis urbibus iam inde servabatur a Romulo, ut propter felicem Sabinarum raptum, Conso, quasi consiliorum Deo, quadrigae septeno currant circumitu; et equos partis adversae fregisse, victoria sit. Hic itaque aemulo suo habente maleficum, qui daemoniacis quibusdam imprecationibus et huius impediret [al. praecantationibus et huius praeparet] equos, et illius concitaret ad cursum, venit ad beatum Hilarionem, et non tam adversarium laedi, quam se defendi obsecravit. Ineptum visum est venerando seni in huiuscemodi nugis orationem perdere. Cumque subrideret et diceret: Cur non magis equorum pretium pro salute animae tuae pauperibus erogas? Ille respondit, functionem esse publicam; et hoc se non tam velle, quam cogi: nec posse hominem Christianum uti magicis artibus; sed a servo Christi potius auxilium petere, maxime contra Gazenses adversarios Dei: et non tam sibi quam Ecclesiae Christi insultantes. Rogatus ergo a fratribus qui aderant, scyphum fictilem quo bibere consueverat, aqua iussit impleri, eique tradi. Quem cum accepisset Italicus, et stabulum, et equos, et aurigas suos, rhedam, carcerumque repagula aspersit. Mira vulgi exspectatio: nam et adversarius hoc ipsum irridens, diffamaverat; et fautores Italici sibi certam victoriam pollicentes exsultabant. Igitur dato signo hi advolant, illi praepediuntur. Sub horum curru rotae fervent, illi praetervolantium terga vix cernunt. Clamor fit vulgi nimius [Codd. nimius attollitur]: ita ut Ethnici quoque ipsi concreparent, Marnas victus est a Christo. Porro furentes adversarii, Hilarionem maleficum Christianum ad supplicium poposcerunt. Indubitata ergo victoria et illis, et multis retro Circensibus plurimis fidei occasio fuit."

\footnotetext{
${ }^{3}$ Szent Jeromos: „Vita Hilarionis” 16.
} 
„Egy másik történet Italicusról szól, aki ugyanabban a városban lakott. Keresztény volt és lovakat tartott a cirkuszi játékokra. Gaza duumvirének ellenfele volt, mert ő Marnas bálványát tartotta tiszteletben. A kocsiversenyek szokása a római városokban olyan régi volt, hogy Romulus idejére nyúlt vissza, és azért vezették be, hogy megemlékezzenek a szabin nők sikeres elrablásáról. A kocsik hétszer kerülték meg a cirkuszt Consus tiszteletére, aki a tanácsadás istensége volt. Aki ki tudta fársztani az ellenfél lovait, elnyerte a győzelmet. Csakhogy most Italicus ellenfele megfizetett egy mágust, hogy bizonyos démoni varázsénekekkel sarkallja győzelemre lovait, és tartsa vissza ellenfelének fogatát. Ezért aztán Italicus az áldott Hilarionhoz ment, és segítségét kérte, de nem azért, hogy ártson ellenfelének, hanem azért, hogy öt magát megoltalmazza. A tiszteletre méltó öreg számára elfogadhatatlan volt, hogy az imát ilyen csekélységekre pazarolja el. Elmosolyodott, és így szólt: Miért nem adod inkább a lovaid árát a szegényeknek, hogy megmentsed a lelkedet? Ő pedig azt felelte erre, hogy a hivatala közügy, és nem annyira szabad választásából, mint inkább kötelességéből ered, minthogy egy keresztény nem alkalmazhat mágiát, hanem inkább Krisztus szolgájának segítségét kéri, különösen Gaza népe ellen, amely Isten ellensége, és amely inkább Krisztus egyháza veresége, semmint az ő lovaié felett örvendezne. A jelen lévő szerzetesek kérésére aztán Hilarion meghagyta, hogy töltsenek meg vízzel egy agyagpoharat, amelyből inni szokott, és adják át Italicusnak. Ô pedig vizet permetezett az istállójára és lovaira, a fogathajtókra és a fogatra, valamint a versenysorompókra. A tömeg izgalma a tetőpontra hágott, az ellenfelek nevetgélve gúnyolódtak az előkészületeken, míg Italicus támogatóit boldogság fogta el a győzelemtől, amit biztosnak tartottak. Megadták a jelet. Az egyik kocsi szinte repült a cél felé, a másik pedig bennragadt. Az egyik kocsi alatt izzottak a kerekek, míg a másik hajtó alig tudta szemével követni az elszáguldó versenyző hátát. A tömeg hatalmas kiáltozásba kezdett, és maguk a pogányok is kijelentették, hogy Krisztus legyőzte Marnast. A vesztesek dühödten követelték, hogy Hilariont, mint keresztény varázslót, hurcolják el kivégezni. Ez az egyértelmű cirkuszi győzelem, és még több másik, ami követte, sokakat győzött meg arról, hogy térjenek át a keresztény hitre." ${ }^{4}$

Hilarion korában a pogány Marnas-kultusz még nagyon is létező valóság volt, amely ellen fel kellett venni a harcot.

${ }^{4}$ Szent Jeromos, „Vita Hilarionis” 20. 


\section{KOMMENTÁR}

Egy kocsihajtóra - A kocsihajtók elleni varázslatok közül csak egy észak-afrikai, hadrumetumi példát idézek a 2. századból: „Kössétek meg és tegyétek nehézkessé a kékek és a vörösök lovait, hogy ne tudjanak futni, a kantárnak engedelmeskedni, mozogni, hanem essenek el, törjenek össze, és a kékek és vörösök hajtói boruljanak fel, a kantárt ne tudják tartani, ne tudják lovaikat sem hajtani, sem féken tartani, ne tudjanak sem elöre, sem ellenfelükre nézni, ne tudjanak győzni. Boruljanak fel!"s Hasonló átok érhette a gazai kocsihajtót.

Gaza városa a mai gazai övezetben feküdt, és lakói a filiszteusok voltak. Ez a tengeri nép a bronzkor végén telepedett le a területen. A filiszteusok és a zsidók háborúiról részletesen beszámol a Héber Biblia. ${ }^{6} \mathrm{~A}$ mindkét történetben fontos szerepet játszó gazai cirkusz, vagyis kocsiversenypálya léte kimutatható a 4-6. századig.

felhagy korábbi foglalkozásával - A kocsiversenyeket pogány istenek tiszteletére tartották, Hilarion ezért ragaszkodik hozzá, hogy a kocsihajtó ne vegyen részt többé a versenyekben.

Italicus - a névből nyilvánvaló, hogy született rómairól van szó, nem pedig gazai filiszteusról.

duumvir - Gazában, mint minden római municipiumban évente két polgármestert választottak, őket hívták duumvireknek.

Marnas bálványát - Gaza legfőbb pogány istenét Marnasnak hívták, Hadrianus 131/132-ben vert érmén is ebben a formában nevezik meg görögül az istent (MAPNAC). A név eredete vitatott. Az ókorban Krétáról akarták eredeztetni Marnast, és ezt fantasztikus etimológiákkal szándékoztak alátámasztani. ${ }^{8} \mathrm{~A} 19$. század végén vetették fel, hogy a Marna arámi nyelven azt jelenti: a mi urunk. Vagyis az isten neve ebből a megszólításból eredne. Ezzel az a gond, hogy az ismert arámi nyelvjárásokban vagy marana, vagy maran lenne a szó alakja. A filiszteusok azonban

\footnotetext{
${ }^{5}$ Audollent 1904, Nr. 275.

${ }^{6}$ Gaza ókori történetét röviden összefoglalja Filiu: első fejezete.

7 Humphreys: 534-535.

${ }^{8}$ Pl. bizánci Stephanos szerint a szűz lányokat Krétán állítólag marnannak nevezték, vö. Mussies: 2434.
} 
nem arámiul beszéltek, ezért hibásan is képezhették/átvehették a nevet, vagy az egyenesen (az általunk nem ismert) filiszteus nyelvből származott.

Marnasról nagyon kevés forrást ismerünk. A legkorábbi történeti írás a Historia Augusta Severus Alexander életrajzából származik, ahol a szíriai származású császár így kiált fel: „Ó Marna, ó Iuppiter, ó, halhatatlan istenek!”9 Marna említése a császár keleti származásával magyarázható. ${ }^{10}$ Egyébként az egyetlen kőfelirat, amit Marnas nevével ismerünk, éppen Bosrából, Dél-Szíriából került elő. A görög felirat ugyanúgy Zeussal azonosítja Marnast, mint a krétai eredet hívei.

„Annélos, Kamasanos fia készítette Zeus Marnas Úrnak.”"11

Epiphanios egyházatya értesülése szerint Marnasnak volt sírja is, vagyis egy tipikus ókori keleti meghaló és feltámadó/tovább élő termékenységistennek tekinthető. ${ }^{12}$

Az idézett forrást Szent Jeromos, vagyis Hierónymos írta, amikor 386 és 420 között Betlehemben tartózkodott, valószínüleg 39o-ben. Müvében Marnas kétszer szerepel. Az egyik az idézett Hilarion-féle csoda, a másik pedig egy keresztény asszony, Aristaineté története, akinek három gyermeke is halálos beteg lett. Felkereste Hilariont, és könyörgött neki, hogy gyógyítsa meg gyermekeit. A keresztény asszony remete Szent Antalt is személyesen ismerte, de nem ez győzte meg Hilariont, hogy segítsen, hanem Aristaineté indulatos kifakadása: azért imádkozik Jézushoz, hogy Marnas bálványa a földre hulljon. A szent kimondta Jézus nevét, keresztet vetett a gyermekek teste fölött, és mind feltámadtak. ${ }^{13}$

A legfontosabb forrásunk azonban a Marcus Diaconus által írt Porphyrios-életrajz. Porphyrios Gaza püspöke volt 395 és 420 között, Marcus írása pedig 420 és 431 között keletkezett. Aineias gazai püspök halála után Porphyrios Thessalonikéből érkezett Gazába. A Marnas-hívők azért könyörögtek istenükhöz, hogy adjon esőt, mert a vidéket szörnyü szárazság sújtotta. Az egész városban mindössze 280 keresztény élt, és közel hatvanezer pogány. Az eső mégis akkor jött el, amikor a keresztények fohászkodtak érte Porphyrios vezetésével. ${ }^{14}$ A pogányok megtiltották, hogy a keresztények bármilyen hivatalt betölthessenek városukban. Porphyrios azonban Marcus Diaconussal 401-ben Konstantinápolyba vitorlázott, és kérte a keresztény császárt, hogy lerombolhassák a pogány szentélyeket. Visszatérésük után az összes szentélyt felgyújtották, de Marnas szentélye, a Marneum sértetlen

\footnotetext{
${ }^{9}$ O Marna, o Iuppiter, o di immortales! Alexander Severus 17, 4. Mussies: 2420 . A császár 222 és 235 között uralkodott, vagyis ebben az időszakban hangzott el ez a felkiáltás.

${ }^{10} \mathrm{Ez}$ csak az elbeszélő források legkorábbika, Hadriánus említett érme száz évvel korábbi.

${ }^{11}$ Mussies: 2421.

${ }^{12}$ Ancoratus 106; Mussies: 2429.

${ }^{13}$ Vita Sancti Hilarionis 14.

${ }^{14}$ Vita Sancti Porphyrii 20-21.
} 
maradt. Végül 402 májusában leomlott az isten két koncentrikus oszlopsorral körülvett, kör alakú szentélye, amelynek közepén állt a templom. A keresztények elpusztították, és a helyére egy kereszt alaprajzú keresztény templomot építettek. ${ }^{15}$ Marnas kultusza ugyan ezzel még nem szűnt meg, de a kereszténység egyre jelentősebbé vált ezen a pogány területen is.

Romulus idejére nyúlt vissza - a Consualia ünnepet a hagyomány szerint Romulus vezette be. Erre hívta meg a szomszédos szabinokat, akiknek aztán elrabolták a lányait. ${ }^{16}$ Azt nem említi Plutarchos, hogy kocsiversenyt is rendeztek a Consualián, csak azt, hogy versenyeket, de azt igen, hogy az ünnepet Consuson kívül Neptunus Equestrisnek, vagyis lovas Neptunusnak mutatták be.

Consus tiszteletére, aki a tanácsadás istensége volt - Jeromos az előbb idézett Plutarchos-helyre utal. Ugyanakkor nem említi, hogy Consus alapvetően az aratás és a gabona istene volt, vagyis termékenységisten, mint Marnas.

az áldott Hilarionhoz ment - Hilarion élete kész regény volt. Jeromos könyvéből tudjuk, hogy a gazai Thabathában született, majd remete Szent Antal hírét hallva, mindössze tizenöt éves korában csatlakozott hozzá Egyiptom sivatagában. Csakhogy Antalt akkor már olyan sok híve vette körül, hogy a legkevésbé sem tudott remeteként élni. Hilarion ezért visszaköltözött Gazába, ahol a tengerparti pusztaságba vette be magát. Az elvonult bölcsnek azonban hamar híre ment, és az emberek egyre nagyobb számban járultak hozzá tanácsot kérni. Jeromos több általa végzett csodáról is beszámol, de a látogatók hada láttán a remeteéletre vágyó Hilarion rendre továbbállt. Először visszatért Egyiptomba, Antal tartózkodási helyeit keresve, majd Szicíliába, Jeromos szerint Dalmatiába, de az inkább Argolis lehetett, mivel Dalmatiában nincs Epidauros nevü város. ${ }^{17}$ Végül Cipruson telepedett le egy világtól elzárt helyen, ahol 371-ben elhunyt. Hilarion tehát a remeteség valóságos celebje lett, aki éppen azt tudta legnehezebben megvalósítani, amire a leginkább vágyott: az elmélkedést a magányban.

Miért nem adod inkább a lovaid árát a szegényeknek - Hilarion az alamizsnálkodás keresztényi kötelességére utal. Amikor Hilarion visszatért Egyiptomból remete Szent Antaltól, szülei már nem éltek. Egész örökségét eladta, és a pénzt a szegényeknek adományozta.

\footnotetext{
${ }^{15}$ Mussies: 2418.

${ }^{16}$ Plutarchos, Romulus 15.

${ }^{17}$ Vita Sancti Hilarionis 39.
} 
Ő pedig azt felelte erre, hogy a hivatala közügy - Italicus tehát nem magánemberként lépett fel a Marnas-hívő duumvirral szemben, hanem valamilyen hivatala volt. A másik duumvir azonban nem lehetett, mivel a gazaiak megakadályozták, hogy a keresztények ilyesféle hivatalt betölthessenek. A versenyjátékok rendezője azonban lehetett.

egy keresztény nem alkalmazhat mágiát - ez inkább elvárás volt, de évszázadokon keresztül az ellenkezőjét tapasztaljuk. ${ }^{18}$

a versenysorompókra - a kocsiversenyeket bonyolult rajtgépekkel indították el. A sorompók lehullása tette lehetővé a kocsik kihajtását.

Hilariont, mint keresztény varázslót, hurcolják el kivégezni - a varázslókat többnyire nem üldözte a pogány Róma, sőt szolgáltatásaikat az egész társadalom igénybe vette. A korai keresztények azonban elkeseredett küzdelmet vívtak a pogány babonákkal, köztük a mágiával szemben. A laodiceai zsinaton 364/365-ben megtiltották az egyházi személyeknek, hogy mágusként tevékenykedjenek, és hogy amuletteket készítsenek. ${ }^{19}$ Egy africai zsinati határozat szerint ugyanez a probléma még kétszáz év múlva is aktuális volt:

„diaconus aut clericus magus aut incantator non sit neque phylacteria faciat.”

„Egyetlen diaconus vagy pap sem lehet varázsló vagy jós, és nem készíthet amuletteket." ${ }^{20}$

${ }^{18}$ Graf (2013): 299-310.

${ }^{19}$ Graf (2013): 304-305.

${ }^{20}$ Graf (2013): 305. 


\section{IRODALOM}

Audollent, Auguste: Defixionum tabellae quotquot innotuerunt tam in Graecis Orientis, quam in totius Occidentis partibus propter Atticas, in Corpore Inscriptionum Atticarum editas, Fontemoing, Paris, 1904.

Filiu, Jean-Pierre: Histoire de Gaza, Paris, 2012.

Graf, Fritz: „The Christian Transformation of Magic”, in Mito y Magia en Grecia y Roma. Edited by Suárez de la Torre, Emilio - Pérez Jimenez, Barcelona, Aurelio, 2013, 299-310, 299-310.

Humphrey, John H.: Roman Circuses: Arenas for Chariot Racing, Berkeley, Los Angeles, 1986.

Jerome, Saint: The Sacred Writings of Saint Jerome. Edited by Schaff, Philipp. Altenmünster, 2012.

Mussies, Gerard: Marnas, God of Gaza, Aufstieg und Niedergang der römischen Welt, 2, 18/4, Berlin, New York 1990, 2412-2457.

Weingarten, Susan: The Saint's Saints. Hagiography and Geography in Jerome, Berlin, New York, 2005. 